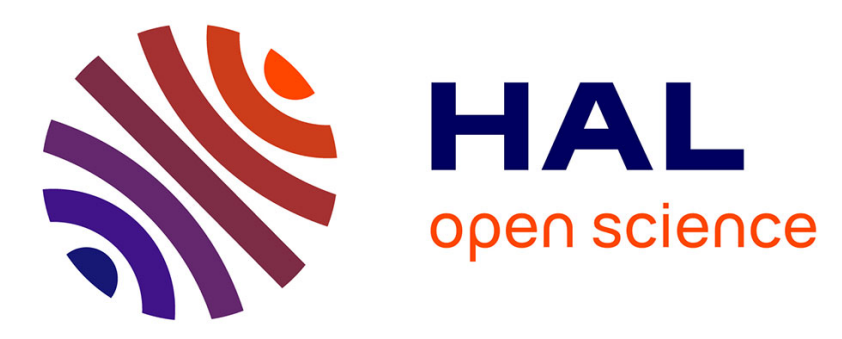

\title{
Stone uses in Reims Cathedral: provenance, physical properties and restoration phases
}

Aurélie Turmel, Gilles Fronteau, Céline Thomachot-Schneider, Claire Moreau, Laurent Chalumeau, Vincent Barbin

\section{To cite this version:}

Aurélie Turmel, Gilles Fronteau, Céline Thomachot-Schneider, Claire Moreau, Laurent Chalumeau, et al.. Stone uses in Reims Cathedral: provenance, physical properties and restoration phases. The Geological Society, London, Special Publications, 2014, 391 (1), pp.17 - 30. 10.1144/SP391.7 . hal01689083

\section{HAL Id: hal-01689083 \\ https://hal.science/hal-01689083}

Submitted on 11 Apr 2018

HAL is a multi-disciplinary open access archive for the deposit and dissemination of scientific research documents, whether they are published or not. The documents may come from teaching and research institutions in France or abroad, or from public or private research centers.
L'archive ouverte pluridisciplinaire HAL, est destinée au dépôt et à la diffusion de documents scientifiques de niveau recherche, publiés ou non, émanant des établissements d'enseignement et de recherche français ou étrangers, des laboratoires publics ou privés. 


\title{
Stone uses in Reims Cathedral: provenance, physical properties and restoration phases
}

\author{
Aurélie TURMEL*, Gilles FRONTEAU**, Céline THOMACHOT-SCHNEIDER, Claire MOREAU, Laurent \\ CHALUMEAU \& Vincent BARBIN
}

GEGENAA (EA3795), Université de Reims Champagne-Ardenne (URCA), 2 Esplanade Roland Garros, 51100 Reims, France

\footnotetext{
* First corresponding author: Aurélie Turmel. e-mail: aurelie.turmel@etudiant.univ-reims.fr

** Alternative Corresponding author: Gilles Fronteau: gilles.fronteau@univ-reims.fr
}

\begin{abstract}
:
Reims Cathedral is a major monument in the NE of France originally built with local Lutetian limestone. The recent closure of the last quarries has made restoration using the same stone more complicated. The restoration stones used currently are Lutetian limestones from the centre of the Paris Basin (SaintPierre-Aigle and Saint-Maximin stones). Mapping of the Cathedral's fac, ades confirmed the data from ancient manuscripts: Courville stone was the original building stone, but several other local stones from various quarries and beds were also used. As a follow-up to this mapping, Lutetian limestones from five disused quarries were sampled for petrophysical characterization tests: thin section analyses, porosimetry, capillary and drying kinetics. The petrophysical properties of the limestones showed differences between the two main local stone types (Ditrupa limestone and miliolids limestone) and also between the quarries. This study addresses the difficulty of selecting new stone for restoration. Should ancient quarries be re-opened? If so, which ones?
\end{abstract}

Keywords: Building stone, lutetian limestone, monument, Reims Cathedral, petrophysic, petrography.

\section{Introduction}

Reims is located in the NE of the Paris Basin, in the Champagne region at the border of the lle-deFrance cuesta (Fig. 1). Founded by the Gauls, the city was the capital of Gallia Belgica during the Roman Empire. Because of its long history and importance in the region, the city has many historical buildings. The gothic Notre-Dame of Reims Cathedral and the Archbishop's Palace are well known, but the city also has a basilica, a triumphal arch and a Gallo-Roman forum. As identified in other countries (Hyslop \& Albornoz-Parra 2009; Unterwurzacher et al. 2010), the original building materials generally came from local quarries. The city was extensively damaged during World War I and the reconstruction used building materials from other regions of France.

In Reims, the main local limestone used in the construction of many monuments is known as Courville stone. However, limestones from surrounding areas were also used in the city's vernacular buildings and other monuments. These included other types of Eocene limestones from the Oise and Aisne sections to the west (e.g. the Saint-Maximin and the Saint-Pierre-Aigle limestones), and Jurassic 
Turmel A., FRONTEAU G., C. Thomachot- Schneider, L. Chalumeau, V. Barbin. 2014. Stone uses in Reims Cathedral: provenance, physical properties and restoration phases. Stone in Historic Buildings: Characterization and Performance. Dir. Cassar J. SP391. Geological Society, London, p. 17-30. doi.org/10.1144/SP391.7Re

limestones from three regions to the east: Meuse (e.g. the Savonnieres and Euville limestones), the French Ardennes (e.g. the Romery limestone)and Burgundy (e.g. the Massangis limestone).

While Courville stone has already been studied (Blanc et al. 1990; Vergès-Belmin 1992; Leroux \& Boutin 1999; Lefèvre et al. 2007), little is known about the use and behaviour of other local building stones. The aim of this study is to understand the use of local Lutetian limestones in the Notre-Dame of Reims Cathedral, as well as to determine the physical behaviour of the other stones. The identification and mapping of the types of stone provided a distribution pattern of the Cathedral's stones. This was followed by sampling and testing of the stone that was taken from disused local quarries to order to obtain petrographical and petrophysical measurements.

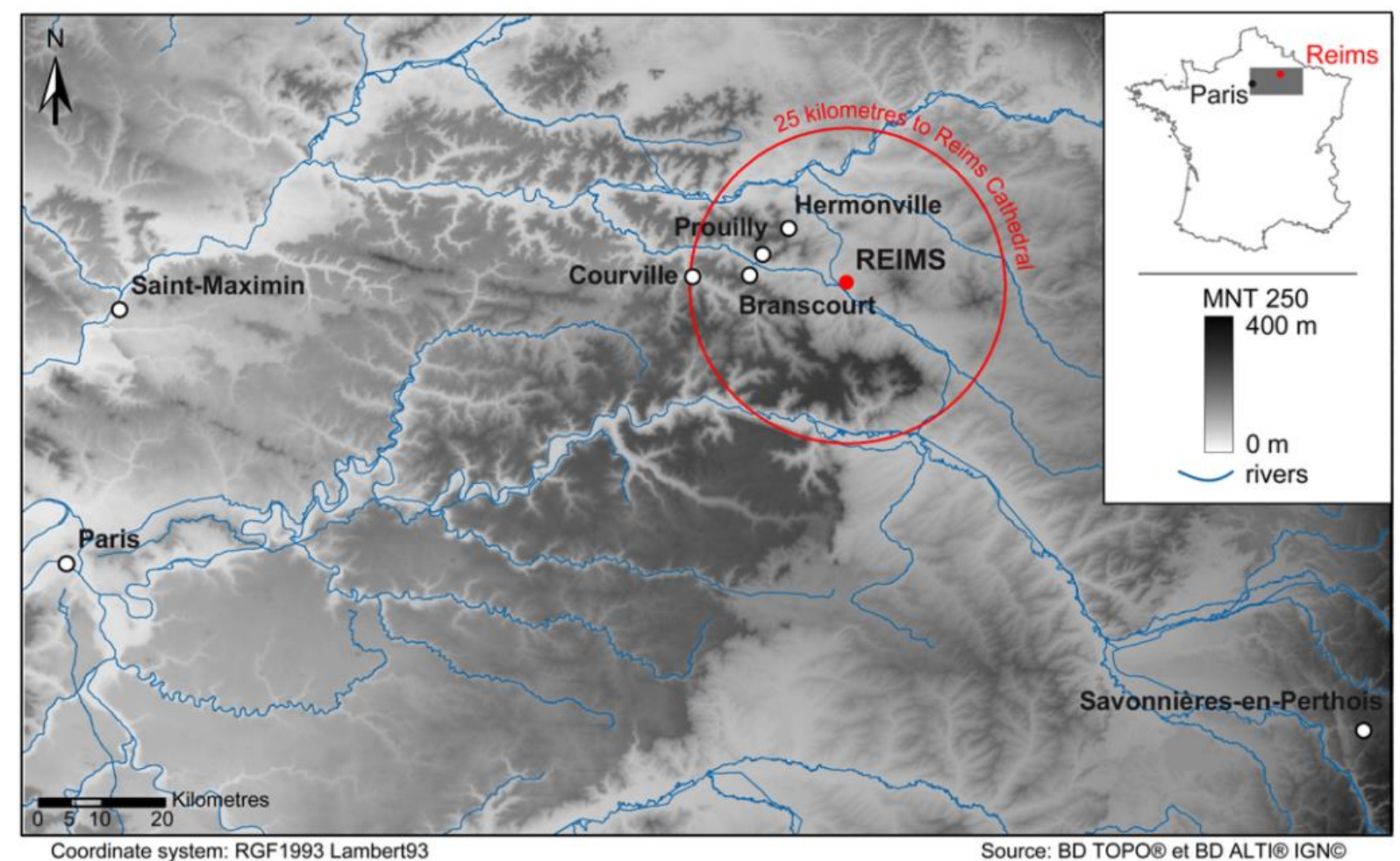

Fig. 1. Localization map of the studied area the geographical coordinate system was RGF 1993 Lambert 1993 and the altitude and topographic data were extracted from the databases BD ALTI and BD TOPO product by the IGN.

\section{The monument: Notre-Dame of Reims Cathedral}

Construction of Reims Cathedral, commissioned by the Archbishop Albe'ric de Humbert, started in 1211 and was completed by the end of the thirteenth century, with the addition of the western part in the fourteenth century. The coronation of most French kings has taken place in the Cathedral. The Cathedral is an excellent example of the classical Gothic style of the second part of the Middle Ages, and is listed as a UNESCO World Heritage Site ( $\left.N^{\circ} 601\right)$. The selection of replacement stones was based not only on the knowledge of local resources, but also for reasons of contemporary trends in styles, cost and personal preferences. Since the nineteenth century, there have been four main phases of restoration.

From 1860 to 1870, Viollet-le-Duc, an architect well known for his idealized restorations of medieval buildings, led the restoration. He ordered work on the apse and on parts of the chancel with stones from surrounding regions instead of local quarries. The term 'local quarries' was defined in accordance with an ancient text that describes a carriage as being able to cover $25 \mathrm{~km}$ in a day. During World War 
I, the Cathedral was severely damaged, in particular by the fire of 19th September 1914. The architect Henri Deneux rebuilt the roof structure with concrete slabs and restored several other parts.

From 1920 until 2005, stone was supplied from Courville, about $20 \mathrm{~km}$ west of Reims. Other local quarries were no longer used and closed after World War I, so the Courville quarry was the last remaining one. This quarry was so renowned that their stone was known as 'the Reims Cathedral stone'. During recent preparatory studies made to guide restoration work, surveys were conducted on the Cathedral to understand the weathering of its Courville stone (Blanc et al. 1990; Vergès-Belmin 1992; Leroux \& Boutin 1999). In the past 5 years, stone from the Courville Quarry was used for a number of restorations. After the recent closure of the last quarry in Courville, restoration building stone has been exclusively from the Oise area (e.g. Saint-Maximin stone), $100 \mathrm{~km}$ from Reims. If future restoration is to be sourced from local quarries, better knowledge of the stone resources is required and, in addition, various trials of substitute stones are planned.
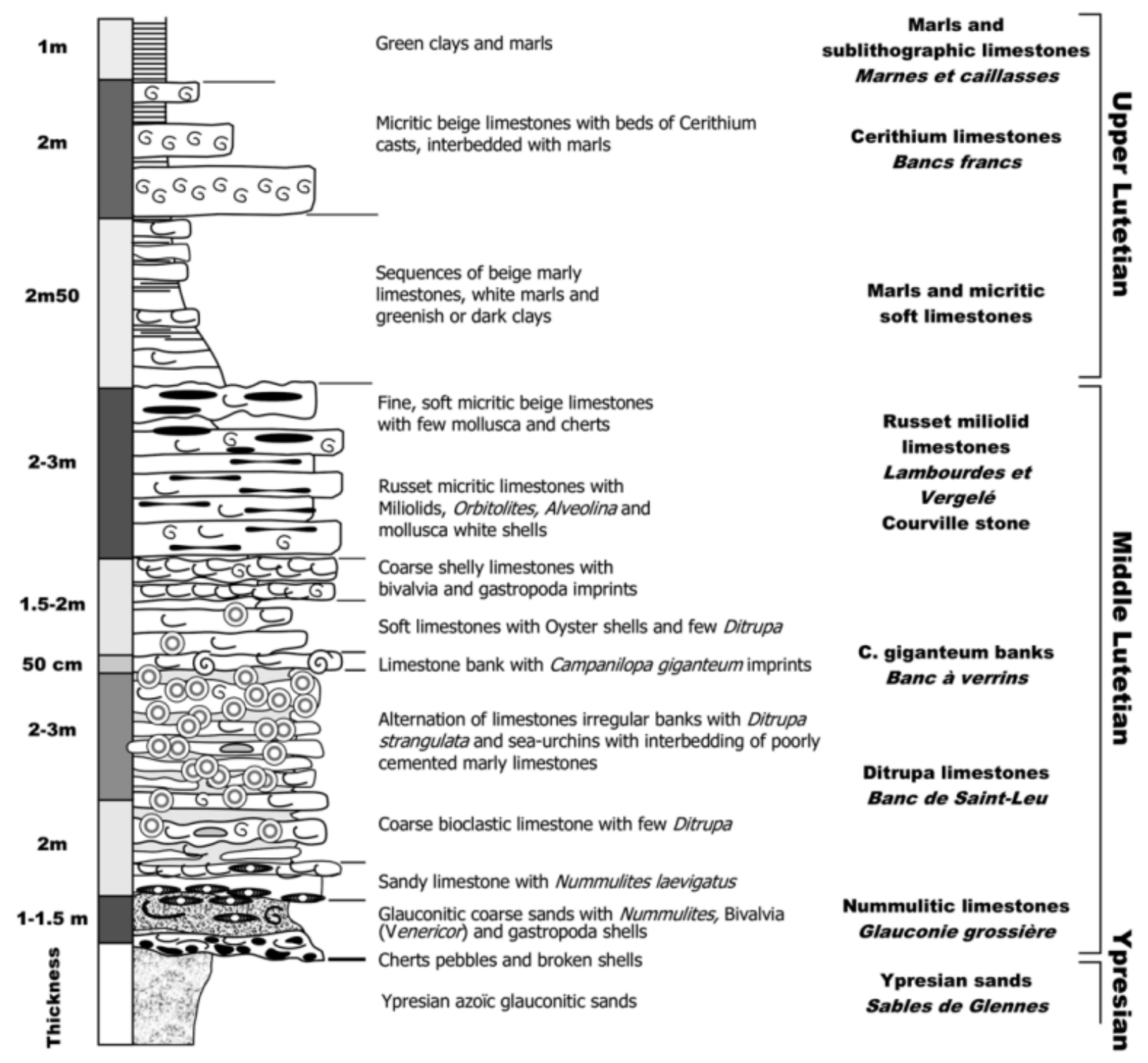

Fig. 2. Stratigraphical log of the Lutetian around Reims. 


\section{Lutetian building stones}

The Lutetian formations display important horizontal and vertical sedimentary variability (Gély 1996; Fröhlich \& Schubnel 2000; Huyghe et al. 2012). The stratigraphical sequence study was carried out locally, with field observations being made in several villages around Reims (Figs 1 \& 2). The Middle Lutetian sequence (Fig. 2) begins with approximately 1-1.5 m-thick detrital biogenic and glauconitic sand; above this, is a 2 m-thick layer of sandy limestone with Nummulites Laevigatus and coarse bioclastic limestone with Ditrupa. Then there is a 3.5-5 m-thick layer of irregular limestone beds with Ditrupa, or 'Banc de Saint-Leu' layer, alternating with interbedding of poorly cemented marly limestones. The middle top layer, 2-3 m thick, is made up of micritic limestone with miliolid and Orbitolites complanatus, also called 'Lambourdes et Vergelé'. The $2 \mathrm{~m}$-thick Upper Lutetian beds consist of a series of distinct beds: marly pale yellowish brown limestones; Cerithium biogenic limestones; discontinuous beds of cherts; and, finally, green lacustrine Limnea limestones, marls and clays.

In the Paris Basin, building stones are mainly extracted from three different strata of the Lutetian sequence: $1 /$ the 'Banc de Saint-Leu' limestone, which is the lower part of the Ditrupa limestones from the Middle Lutetian; 2/ the 'Lambourdes et Vergelé', which are the upper part of Middle Lutetian limestones; and 3/ the'Banc franc'or'Banc de roche', which belong to the Upper Lutetian Cerithium limestones.

It is difficult to establish a link between the name and the origin of a stone. The name of a stone can refer to the geological composition, the location of the quarry, its colour or use (Viré 1997); for example. 'Liais de Courville' or 'Roche franche fine de Saint-Maximin' and other such names may change over time.

As Reims is located near the eastern limit of the marine Lutetian limestone deposit, the thickness and the number of beds can vary greatly within a short distance. For instance, in the centre of the basin, the Lutetian Formation to the west is thicker than in the Reims area (Huyghe et al. 2012). In Soissons (50 km west of Reims), the "Lambourdes et Vergele" limestones are $10 \mathrm{~m}$ thick, whereas, on the eastern border of the Paris Basin, this decreases to about $3 \mathrm{~m}$ (Blondeau 1970) and disappears south of Reims, where they are replaced by continental Lutetian deposits.

The lateral variability of the formation also suggests a variation in petrophysical properties (Fronteau et al. 2010). Today, most of the Lutetian limestone quarries in the Paris Basin are located in the Oise region, with two further ones sited north, in the Aisne region. The last quarry situated near Reims, closed in 2005. Here, an orange brown, miliolid limestone was extracted mainly for restoration purposes.

With the closure of the last quarry to provide local limestones, the question of restoration stone supplies arises, and points to the lack of information on the variability of the stones in the monument itself and in the area surrounding Reims. Many studies have examined the Paris Basin Lutetian building stones, but mainly those from the Oise region (Bousquie' 1979; Beck 2006; Angeli et al. 2008; Moreau 2008).

\section{Material and methods}

\section{Mapping and field sampling}


Turmel A., FRONTEAU G., C. Thomachot- Schneider, L. Chalumeau, V. Barbin. 2014. Stone uses in Reims Cathedral: provenance, physical properties and restoration phases. Stone in Historic Buildings: Characterization and Performance. Dir. Cassar J. SP391. Geological Society, London, p. 17-30. doi.org/10.1144/SP391.7Re

Mapping of the building stones used in Reims Cathedral was carried out for two sections: the northern upper part of the apse and its foundation; and the lower part of the outer south wall, at the level of the sixth buttress of the nave.

In parallel, drill-core samples, $50 \mathrm{~mm}$ in diameter and $50+0.5 \mathrm{~mm}$ in length, from the central part of blocks of Ditrupa limestones 'Banc de Saint-Leu' were taken for laboratory testing. These samples were taken from a number of local open quarries, as given below: Hermonville: eight drill cores (Her2) and five drill cores in quartzic limestones (Her1); Prouilly: six drill cores (Pro); Branscourt: nine drill cores (Bra).

Additional sampling of the orange brown miliolid limestones "Lambourdes et Vergele" was carried out in local underground quarries: four drill cores in Branscourt (BraL) and eight drill cores in Courville stones (CouL).

\section{Petrographical analyses}

The microfacies, using the Folk (1959) and Dunham (1962) classifications, characterizes the stone composition and the macroporosity. Thin sections were studied using a polarizing Olympus BX51 microscope linked to a QICAM Fast1394 highresolution camera and operating image analysis software from Microvision Instrument.

\section{Pore space analysis}

The effective porosity, Nt, was measured according to the AFNOR B10-615 standard (AFNOR 2007). Samples were dried at $708 \mathrm{C}$ to constant mass (Ws) and placed under vacuum (15 mm Hg) for $2 \mathrm{~h}$. Then, water was continuously and slowly added under vacuum, until samples were totally covered. The vacuum was released and samples were left under water at atmospheric pressure for $24 \mathrm{~h}$. Samples were weighed under water (W1) and after rapid surface drying with a dampened soft cloth to determine the mass (W2) of the watersaturated sample. The effective porosity is given by the following equation:

$$
\mathrm{Nt}=\left(\mathrm{W}_{2}-\mathrm{W}_{\mathrm{s}}\right) /\left(\mathrm{W}_{2}-\mathrm{W}_{1}\right)
$$

The porosity and pore-size characterization were performed by mercury-intrusion porosimetry, whereby the pores of the sample were filled with mercury (a non-wetting liquid), using different pressure increments. Measurements were performed using a Micromeritics Autopore IV 9500 porosimeter, with a pore radius size ranging from $180(0.004 \mathrm{MPa})$ to $0.003 \mathrm{~mm}(274 \mathrm{MPa})$. The mean poreradius, $\mathrm{Rm}$, is the inflexion pointon the cumulative intrusion curves; $\mathrm{Rm}(\mathrm{mm})$ gives information on the mean pore throat radius. The scatter coefficient, $\mathrm{Cd}$, is calculated from the ratio of injection pressures using equation (2), and provides information on the dispersion of pore-size distribution:

$$
C d=\left(P_{80}-P_{20}\right) / P_{50}
$$

where $\mathrm{P}_{80}, \mathrm{P}_{50}$ and $\mathrm{P} 20$ are the pressures at 80,50 and $20 \%$ of porosity volume filled with mercury, respectively.

If $\mathrm{Cd}=1$, the pore distribution is concentrated around one pore throat size. If $\mathrm{Cd}>1$, the distribution is more varied and thus the porous network is more complex (Remy 1993). The microporosity values $\mathrm{P}_{\mathrm{m} 0.05}, \mathrm{P}_{\mathrm{m} 0.1}$ and $\mathrm{P}_{\mathrm{m} 5}$ represent porosities smaller than $0.05,0.1$ and $5 \mathrm{~mm}$, respectively (Yu \& Oguchi 2010; Thomachot-Schneider et al. 2011).

\section{Capillary properties}


Turmel A., FRONTEAU G., C. Thomachot- Schneider, L. Chalumeau, V. Barbin. 2014. Stone uses in Reims Cathedral: provenance, physical properties and restoration phases. Stone in Historic Buildings: Characterization and Performance. Dir. Cassar J. SP391. Geological Society, London, p. 17-30. doi.org/10.1144/SP391.7Re

The capillary water uptake was measured according to the standard AFNOR B10-613 (AFNOR 1999). Samples were placed in $5 \mathrm{~mm}$ of water in a closed container to maintain a relative humidity $(\mathrm{RH})$ of $100 \%$. The weight, $\mathrm{W}$, was regularly measured. According to the Washburn equation, the weight gain is directly proportional to the square root of time (see equation 3 ):

$$
\mathrm{dW} / \mathrm{S} \mathrm{C} 1 \mathrm{t}^{-1}
$$

where $\mathrm{dW}$ is the water uptake $(\mathrm{g}), \mathrm{S}$ represents the contact surface $(\mathrm{m} 2)$ and t corresponds to time $(\mathrm{s})$. On the curve, the slope of the first linear part corresponds to the capillary coefficient, C1 (g m22 s21/2), which represents the water gained per unit surface in function of the square root of time. At the end of this part, the volume of porosity filled by capillary uptake is Ncap (\%) (the volume of porosity invaded by water absorption).

After the water uptake measurements, drying kinetics were performed on the same samples. They were wrapped in a waterproof muff, except for their upper face, and put into a chamber at $33 \% \mathrm{RH}$, maintained by a $\mathrm{MgCl} 2$-saturated solution. Weight was measured regularly and the water loss per surface was plotted over time.

During the first drying period, water is transported to the surface by capillary transfer and the flow, $F$ (g m22 s21), is constant. At the end of this period, the water that remains inside the rock sample is called the critical saturation, Sc (\%). After further drying, the remaining water will mainly evaporate from the interior.

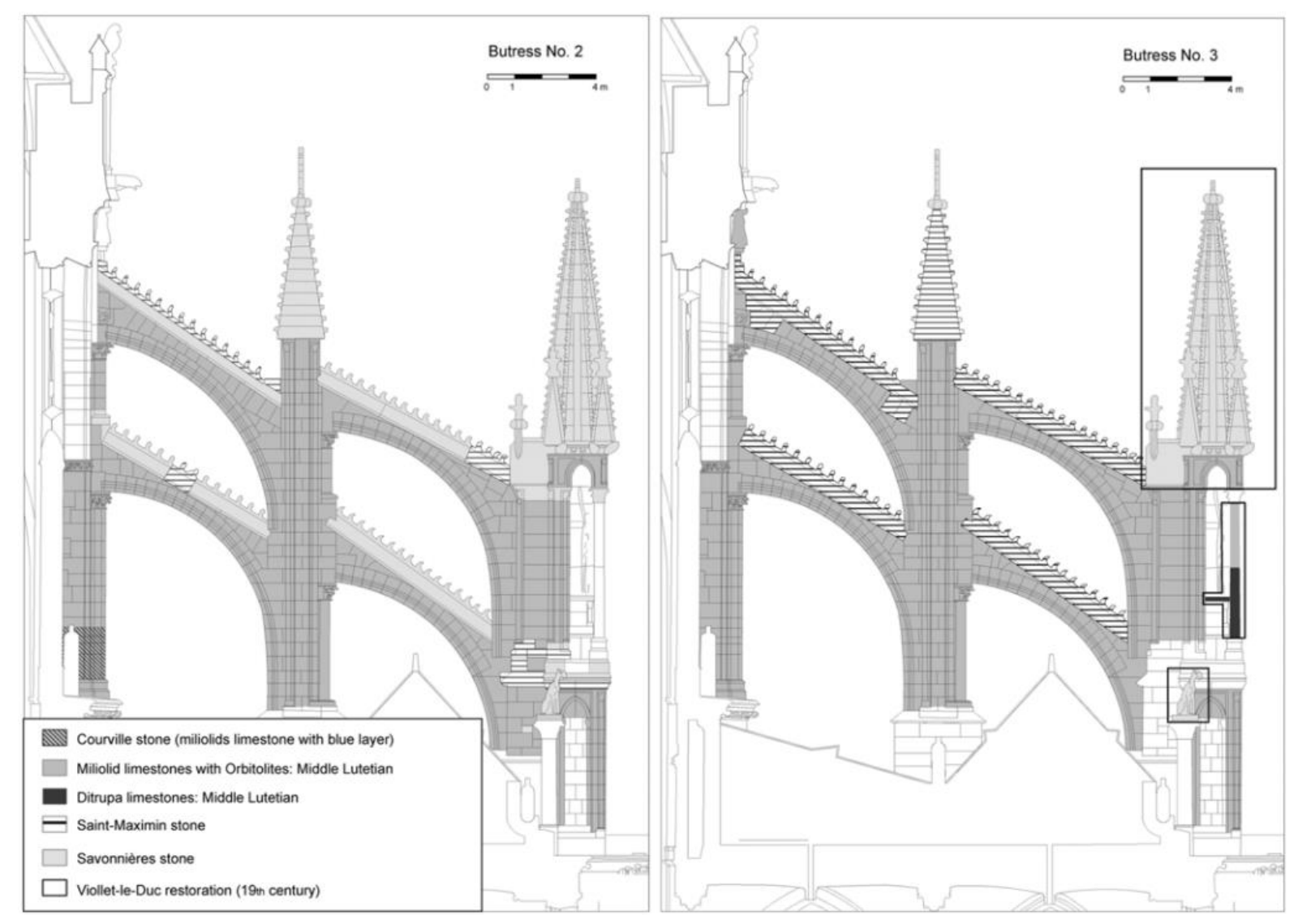

Fig. 3. Stone mapping of buttresses No. 2 (on the left) and No. 3 (on the right) of Reims Cathedral apse. 

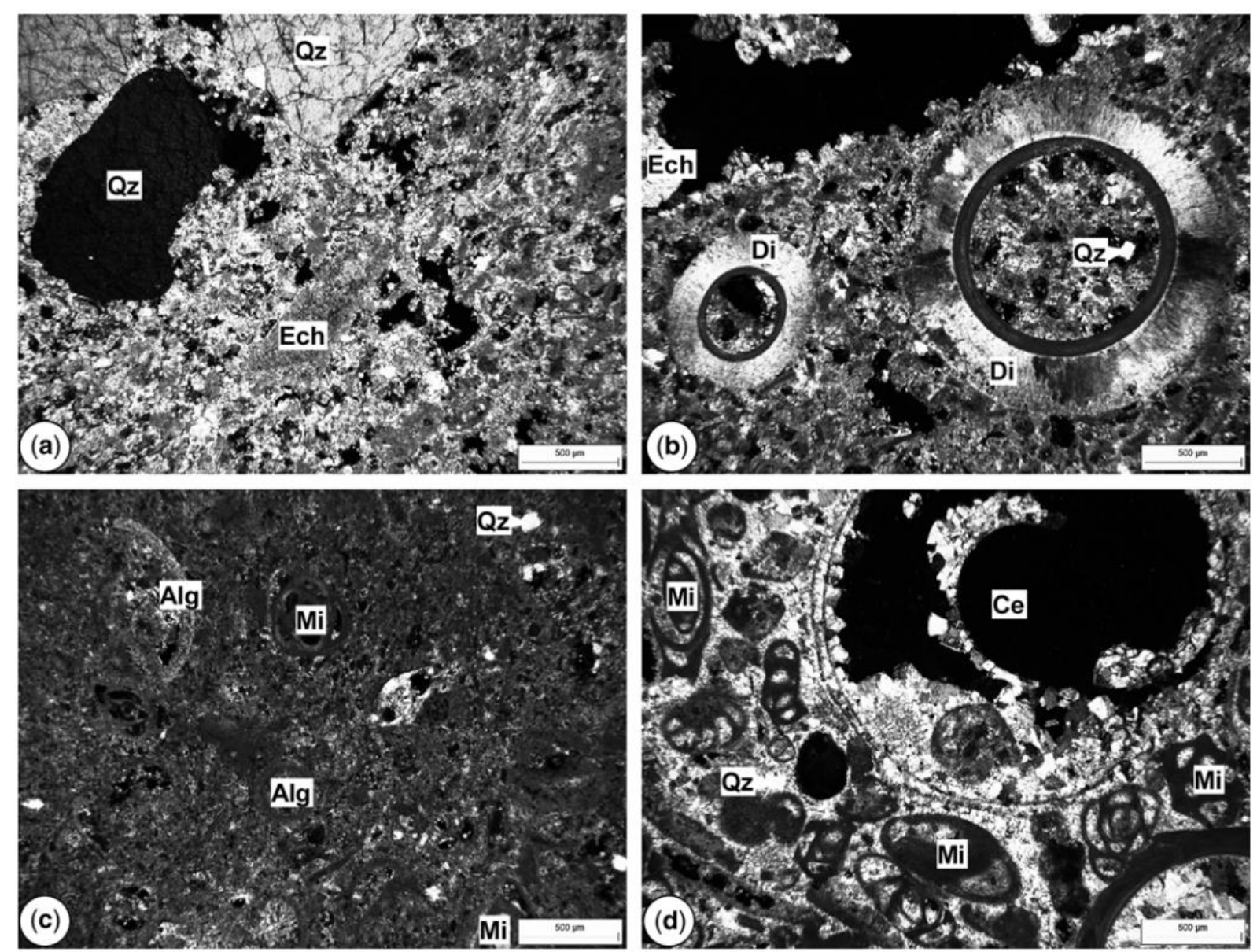

Fig. 4. Polarized images of thin sections of major facies: (a) Ditrupa limestone with quartz grains and glauconite (Her1 and Bra); (b) Ditrupa limestone (Pro, Her2); (c) miliolids limestone (BraL, CouL); (d) Cerithium limestone. Alg, Dasycladacae; Ce, Cerithium; Di, Ditrupa; Ech, echinoderm; Mi, miliolid; Qz, quartz grain.

\section{Results and discussion}

\section{Mapping stone used in the Cathedral}

Stone mapping of the northern parts of the apse showed that the pinnacles were of oolitic limestone from the Savonnières-en-Perthois region (the Savonnie'res stone group from Tithonian) or of SaintMaximin stones (from Lutetian) for the current restoration (Fig. 3). For buttress elevations and the window between the two arches, a local orange brown miliolid limestone was used. At the base of buttress No. 3 on the apse wall, the Courville stone was clearly identified by a specific facies, coming from the Saint-Julien quarry near Courville: a fine orange brown limestone with a blue vein in the centre of the blocks (Middle Lutetian). Caps and decorations of buttresses were of oolitic Savonnie'res or in Saint-Maximin stone (Cerithium Lutetian Limestone) (Figs $3 \& 4 \mathrm{~d}$ ). One column on the pinnacles of buttress No. 2 was composed of miliolid limestones and Ditrupa limestones. The pinnacles of buttress No. 3 were composed of miliolid limestones, and the columns, although identified as Vendresse stone in nineteenth century records, were also of a miliolid limestone.

Absidioles walls were mainly in Ditrupa limestones and miliolids limestones, but, sometimes, lacustrine Limnea limestone was used. The stonecutting marks indicate that these were the original materials (thirteenth century). 
To illustrate the use of stones in the foundation and lower parts of the monument (Fig. 5), the wellpreserved walls near the modern sacristy were studied (south wall, sixth buttress of the nave). This sacristy was mainly built with grey oolitic limestones from the Savonnie'res stone Group and differs from the rest of the monument. The study area is located in the eastern part of the monument, which was built at least 20 years before the western parts. The stone facies was identified during an inspection of seven courses of stone, $2.5 \mathrm{~m}$ high, in the lowest part of the foundation. All were of limestone, coming from various beds of the Lutetian formations, mainly from the Upper Lutetian. Six groups were identified: $1 /$ lacustrine limestone with Limnea (from the Upper Lutetian); 2/Cerithium limestones (from the Upper Lutetian); 3/ micritic limestones with gastropods (perhaps Upper Lutetian); 4/ miliolid and Orbitolites complanatus limestones (from the 'Lambourdes et Vergele" beds, upper part of the Middle Lutetian); 5/ Ditrupa limestones (from the 'Banc de SaintLeu', lower part of the Middle Lutetian); 6/ non-identified Lutetian limestones.

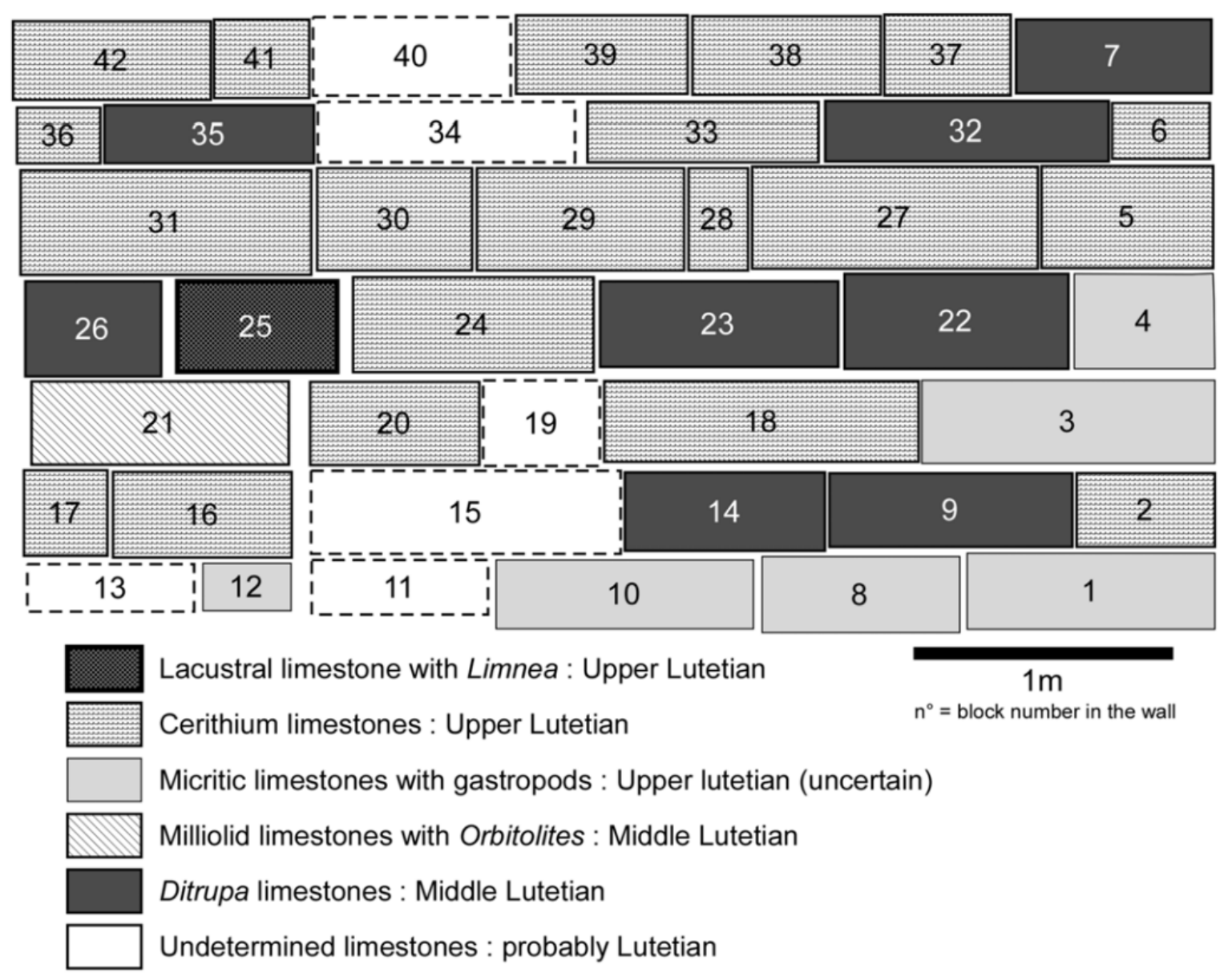

Fig. 5. Stone mapping of the foundation and the lower part on the south wall, sixth buttress, of the nave of Reims Cathedral

The map highlighted the following results:

- No Courville stone (Middle Lutetian) was observed in the foundation, instead there were mainly stones from the Upper Lutetian.

- Traditionally considered as well preserved with little restoration work, this part had many different types of stone (six different facies for 42 described blocks). The different lengths and thicknesses of the blocks emphasized this variation in stone type. 
Turmel A., FRONTEAU G., C. Thomachot- Schneider, L. Chalumeau, V. Barbin. 2014. Stone uses in Reims Cathedral: provenance, physical properties and restoration phases. Stone in Historic Buildings: Characterization and Performance. Dir. Cassar J. SP391. Geological Society, London, p. 17-30. doi.org/10.1144/SP391.7Re

The diversity of stone types may be explained by:

- the ancient undocumented restoration phases in the foundation and lower part of the Cathedral;

- a less-constrained selection of stones in the early stages of building the Cathedral;

- the re-use of stone from older monuments.

These suggestions are not mutually exclusive; a less-stringent selection of stones during this early stage of Cathedral building may include the recycling of blocks from older constructions and some limited restoration afterwards.

A lacustrine limestone, a facies almost exclusively observed in Gallo-Roman buildings of the town (Fronteau et al. 2010), was found as part of the foundation of the Cathedral. This indicates re-use and, thus, the existence of undocumuented restoration phases. Moreover, these limestones were not local, but come from about $50 \mathrm{~km} \mathrm{NW}$ or west of the city. However, during the later Middle Ages, local limestones mainly came from several villages that lie within 15-30 km of Reims, such as Courville or Hermonville (Fig. 1).

\section{Petrographical and petrophysical properties.}

The main local facies were miliolid limestones (Lambourdes et Vergele') and Ditrupa limestones (Banc de Saint-Leu). Laboratory studies were performed on samples of these two beds.

The Ditrupa limestones (from Prouilly (Pro), Branscourt (Bra) and Hermonville (Her1 and Her2)) were typically biomicritic and biomicrosparitic packstones (Fig. 4). The main bioclasts were annelids tubes of Ditrupa strangulata, oyster shells, echinoderm fragments and miliolids (Fig. 4a, b). Sometimes, accumulations of Ditrupa and shells were seen instead of homogeneous spreading of bioclasts in the stone. The matrix was a micrite diagenetically recrystallized into microsparite. The porous network was complex, with intergranular or intragranular pores into and around annelid tubes and miliolid chambers, and with moldic porosity corresponding to the dissolved fossils shells. The main pore sizes varied from 2 to $20 \mathrm{~mm}$. Because the Ditrupa tubes of the Prouilly samples were partially or completely filled with sparite cement, they had a lower macroporosity (Fig. 4b) than the others (Bra, Her1 and Her2). Coarse glauconite and quartz grains were also seen in Bra and Her1 thin sections (Fig. 4a). These two limestones were typical of those from the bottom part of the Ditrupa layer in the Reims region. Her1 and Bra also showed some chalcedony crystallizations in the Ditrupa microstructure.

Branscourt Liais (BraL) and Courville Liais (CouL) were similar miliolid limestones. They were mainly composed of bioclasts of oyster shells, miliolids, Alveolina, Orbitolites complanatus foraminifera and circular sections of Dasycladacae algae(Fig.4c). These biomicrite packstones/wackestones presented a heterogeneous micritic matrix, which was recrystallized into microsparite. The intergranular pores are less than $10 \mathrm{~mm}$ and are not measurable using optical microscopy. The macroporosity comprised of the moldic porosity in dissolved shells and intragranular porosity in foraminifera, forming a poorly connected network.

Next page :

Table 1. Petrophysical properties of Lutetian limestones from the area surrounding Reims 


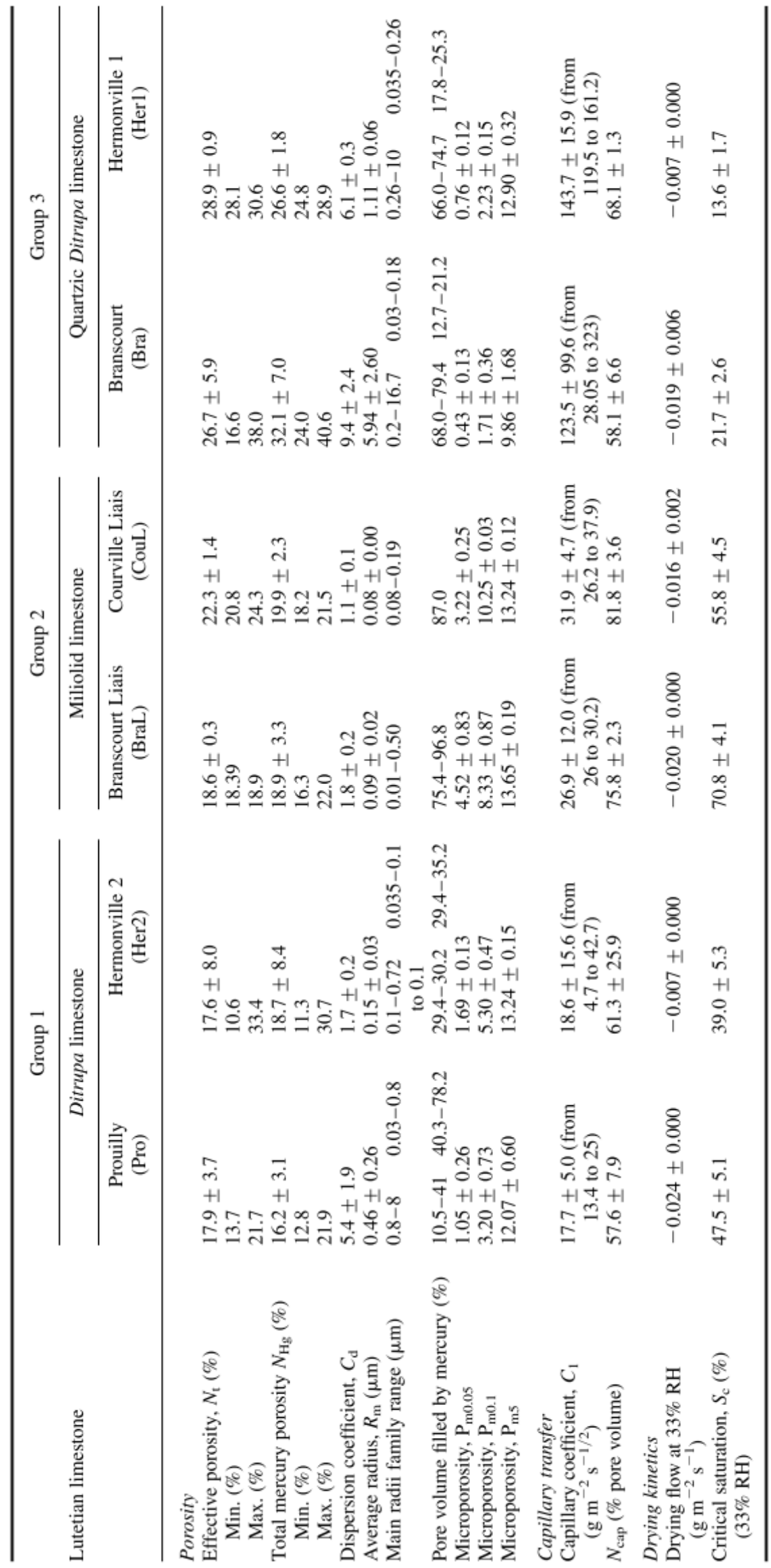


Turmel A., FRONTEAU G., C. Thomachot- Schneider, L. Chalumeau, V. Barbin. 2014. Stone uses in Reims Cathedral: provenance, physical properties and restoration phases. Stone in Historic Buildings: Characterization and Performance. Dir. Cassar J. SP391. Geological Society, London, p. 17-30. doi.org/10.1144/SP391.7Re
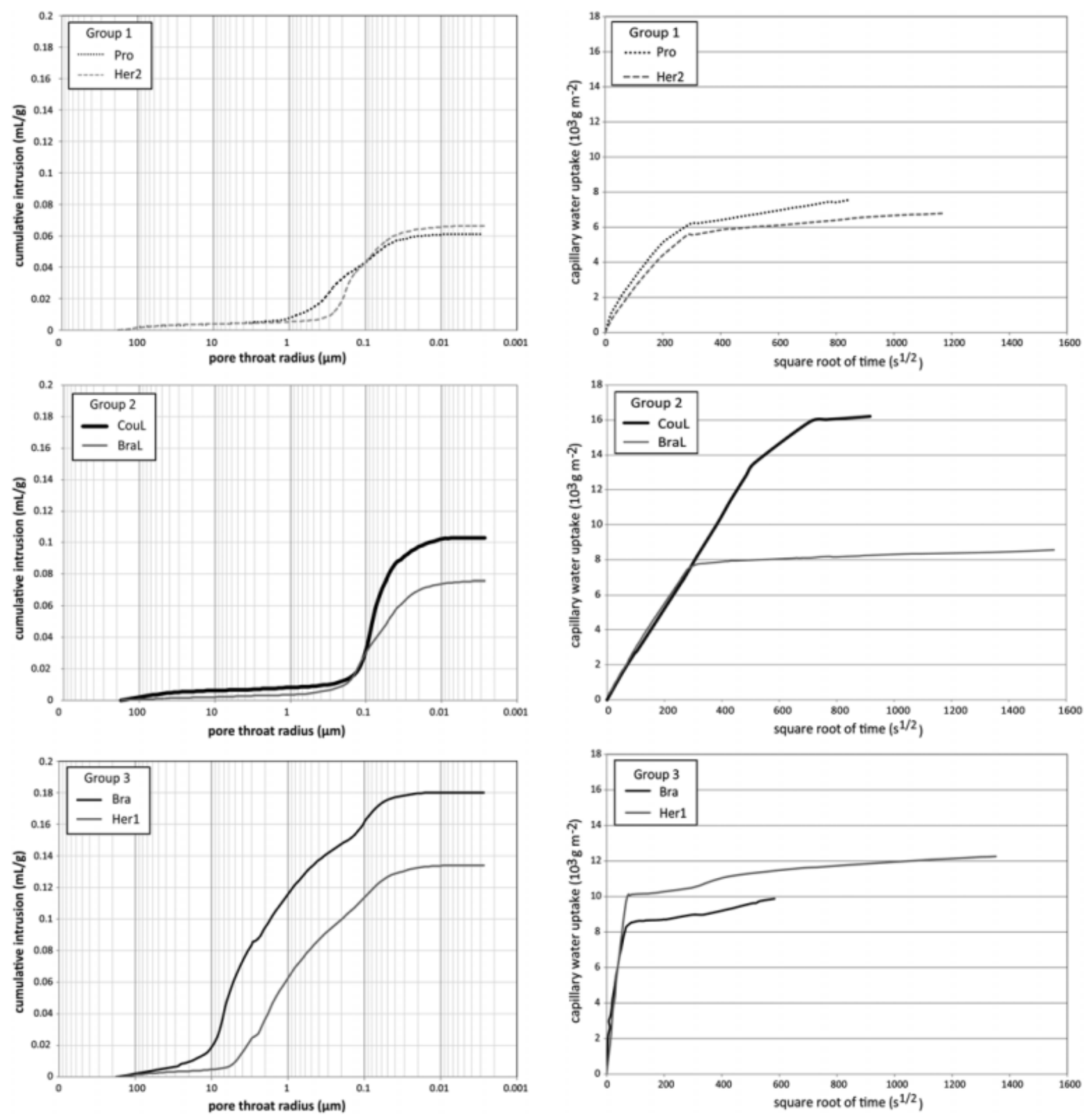

Fig. 6. Cumulative intrusion mercury v. pore access radii representative curves for each Lutetian limestone.

Fig. 7. Typical capillary absorption curves of each Lutetian limestone.

The porosity and capillary properties for each building stone were reported in Table 1 . The average effective porosity values were classified into three groups. The first group corresponded to Pro, Her2 Ditrupa limestones; the second group was BraL and CouL miliolid limestones; and the third one, Her1 and Bra Ditrupa limestones with quartz grains. The first and second groups had similar effective porosities of approximately 18 and $20 \%$, respectively. The third group had an effective porosity of around $27 \%$.

With regard to the mercury porosimetry, groups 1 and 2 had porosities of around 18\%, whilst Group 3 had a higher porosity of $29 \%$. In Group 1, the cumulative intrusion curves of Pro samples were shifted to the left, indicating a more macroporous network than the other samples (Fig. 6). In the same way, Her2 was more macroporous than BraL. The scatter coefficient, $\mathrm{Cd}$ (Table 1), shows that Pro (Cd 1/4 5.4) 
Turmel A., FRONTEAU G., C. Thomachot- Schneider, L. Chalumeau, V. Barbin. 2014. Stone uses in Reims Cathedral: provenance, physical properties and restoration phases. Stone in Historic Buildings: Characterization and Performance. Dir. Cassar J. SP391. Geological Society, London, p. 17-30. doi.org/10.1144/SP391.7Re

was 3 times greater than BraL ( $\mathrm{Cd} 1 / 4$ 1.8) and Her2 ( $\mathrm{Cd} 1 / 4$ 1.7). The higher values indicate a more heterogeneous pore throat network. Thus, the $\mathrm{Rm}$ value for these stones was not significant. However, the low dispersion coefficient of CouL (1.1) meant that the pore network was dominated by a similar pore size. The $\mathrm{Cd}$ value close to 1 indicates a normal distribution of the pore access radii, so the $\mathrm{Rm}$ value is significant for this sample and represented an access pore radius of $0.08 \mathrm{~mm}$.

For the third group, the cumulative intrusion curves were shifted further to the left than those from the first and second groups, indicating a network with more macropores (Fig. 6). This is confirmed by the study of the microporosity of less than $0.1 \mathrm{~mm}$ filled by mercury (Pm0.1). Pm0.1 for Group 2 (CouL 10.25\% and BraL 8.33\%) was double that of Group 1 (Her2 5.30\% and Pro3.20\%) and 5 times higher than Group 3 (Her1 2.23\% and Bra 1.71\%). The scatter coefficients (Cd) were the highest, with 9.4 and 6.1 for Group 3. These results and the shape of the curves (Fig. 6) indicate that these two stones have a heterogeneous pore-size distribution. Two main radii ranges could be distinguished for these two limestones: one from about 0.03 to $0.2 \mathrm{~mm}$; and the other one from around 0.2 to $10-16$ $\mu \mathrm{m}$ (Table 1).

The water uptake, defined by the capillary absorption coefficient, $C 1$, was similar for Group 1 with, respectively, $17.7 \pm 5$ (Pro) and $18.6 \pm 15.6 \mathrm{~g} \mathrm{~m}-2 \mathrm{~s}-1 / 2$ (Her2) (Table 1 and Fig. 7a). The open pore volume (Ncap) of 61.3 (Pro) and 57.6\% (Her2) was reached in $23 \mathrm{~h}$. CouL and BraL had similar values, but equilibrium was reached in half the time of that for Pro and Her2. C1 was $31.9 \pm 4.7 \mathrm{~g} \mathrm{~m}-2 \mathrm{~s}-1 / 2$ for CouL and $26.9 \pm 12 \mathrm{~g} \mathrm{~m}-2 \mathrm{~s}-1 / 2$ for BraL. Ncap was also higher, with $75.8 \%$ reached in $23 \mathrm{~h}$ (BraL) and $81.8 \%$ reached in $73 \mathrm{~h}$ (CouL). Comparatively, C1 of Group 3 ( $27 \%$ of total porosity) was 7 times higher than Group 1, $123.5 \pm 99.6 \mathrm{~g} \mathrm{~m}-2 \mathrm{~s}-1 / 2$ for Bra and $143.7 \pm 15.9 \mathrm{~g} \mathrm{~m}-2 \mathrm{~s}-1 / 2$ for Her1. The percentage of porosity filled at the end of the capillary absorption test was 58.1 (Bra) and $68.1 \%$ (Her1) in $1 \mathrm{~h}$ (Fig. 7).

Drying coefficients at 33\% RH were similar for all of the limestones (Fig. 8). Her1 (Group 3) and Her2 (Group 1) had the lowest drying flow (20.007 g m-2 s-1), while the others had a drying flow of around $20.020 \mathrm{~g} \mathrm{~m}-2 \mathrm{~s}-1$. However, the critical saturation (Sc) - that is, the amount of water remaining in the porous network at the end of the first stage of the drying test (constant flow) - did show differences between the more porous limestones (Group 3) and the others (Group 1 and Group 2). The amount of water remaining after the first stage of drying (Sc) for Ditrupa limestones with quartz grains (Group 1) was 13.6 (Her1) and 21.7\% (Bra), whilst the values for the miliolid limestones (Group 2) were 55.8 (CouL) and 70.8\% (BraL), and for the Ditrupa limestones (Group 3) were 39.0 (Her2) and $47.5 \%$ (Pro).

The stone fabric influences the petrophysical properties of the rocks. Siegesmund et al. (2010) have defined four major fabrics that influence decay: $1 /$ major constituents, such as fossils, ooids and crystals; 2 / pore space; 3 / fractures; 4 / stylolites.

Total porosity, pore-size distribution, pore shapes, water uptake and drying kinetics are used to estimate the stone durability, and, therefore, the use of a specific stone in restoration (Kozlowski et al. 1990; Goudie 1999; Török et al. 2007). In the present study, the pore spaces were analysed for four Ditrupa limestones and two miliolid limestones. Three groups were distinguished according to their pore space and water transfer properties, but not by their petrography. Group 1 (Ditrupa limestones Pro and Her2) and Group 2 (miliolid limestones BraL and CouL) had the lowest porosities. Within them, the petrophysical properties differentiated both. The third group included Ditrupa limestones from Hermonville 1 (Her1) and Branscourt (Bra) with a high total porosity and similar pore distribution. 
Turmel A., FRONTEAU G., C. Thomachot- Schneider, L. Chalumeau, V. Barbin. 2014. Stone uses in Reims Cathedral: provenance, physical properties and restoration phases. Stone in Historic Buildings: Characterization and Performance. Dir. Cassar J. SP391. Geological Society, London, p. 17-30. doi.org/10.1144/SP391.7Re
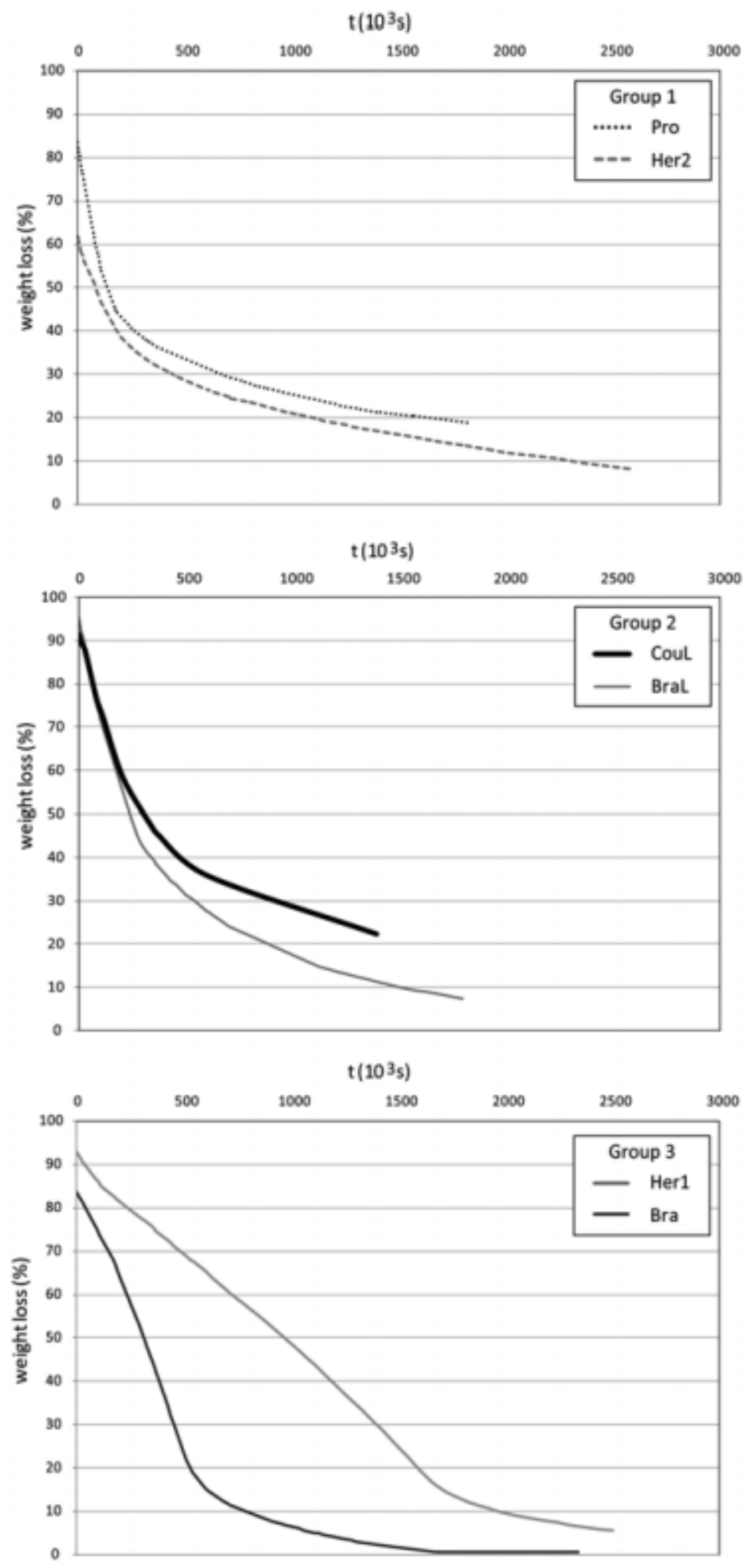

Fig. 8. Typical drying curves presenting the weight loss to the local stones. The effective porosity was (\%) v. time (s) for each Lutetian limestone. 
Turmel A., FRONTEAU G., C. Thomachot- Schneider, L. Chalumeau, V. Barbin. 2014. Stone uses in Reims Cathedral: provenance, physical properties and restoration phases. Stone in Historic Buildings: Characterization and Performance. Dir. Cassar J. SP391. Geological Society, London, p. 17-30. doi.org/10.1144/SP391.7Re

Table 2. Salt Susceptibility Index (SSI) (Yu \& Oguchi 2010) of Lutetian limestones (Ipc, index of the connected pore; Ip0.1, index of pore inferior to $0.1 \mathrm{~mm}$; Pm5/Pc, ratio of the volume of microporosity inferior to $5 \mathrm{~mm}$. connected pore volume)

\begin{tabular}{|c|c|c|c|c|c|c|}
\hline \multirow[b]{2}{*}{$\begin{array}{l}\text { Lutetian } \\
\text { limestone }\end{array}$} & \multicolumn{2}{|c|}{ Group 1} & \multicolumn{2}{|c|}{ Group 2} & \multicolumn{2}{|c|}{ Group 3} \\
\hline & $\begin{array}{l}\text { Prouilly } \\
\text { (Pro) }\end{array}$ & $\begin{array}{l}\text { Hermonville } 2 \\
(\text { Her } 2)\end{array}$ & $\begin{array}{c}\text { Branscourt } \\
\text { Liais (BraL) }\end{array}$ & $\begin{array}{c}\text { Courville } \\
\text { Liais (CouL) }\end{array}$ & $\begin{array}{l}\text { Branscourt } \\
\text { (Bra) }\end{array}$ & $\begin{array}{c}\text { Hermonville } 1 \\
(\text { Her } 1)\end{array}$ \\
\hline$I_{\mathrm{pc}}$ & 5 & 5 & 5 & 5 & 8 & 7 \\
\hline$I_{\mathrm{p} 0.1}$ & 3 & 4 & 5 & 6 & 2 & 2 \\
\hline $\mathrm{P}_{\mathrm{m} 5} / \mathrm{P}_{\mathrm{c}}$ & 0.75 & 0.71 & 0.72 & 0.67 & 0.31 & 0.48 \\
\hline SSI & 5.9 & 6.4 & 7.2 & 7.3 & 3.1 & 4.4 \\
\hline Result & Salt prone & Salt prone & Salt prone & Salt prone & Salt resistant & Salt prone \\
\hline
\end{tabular}

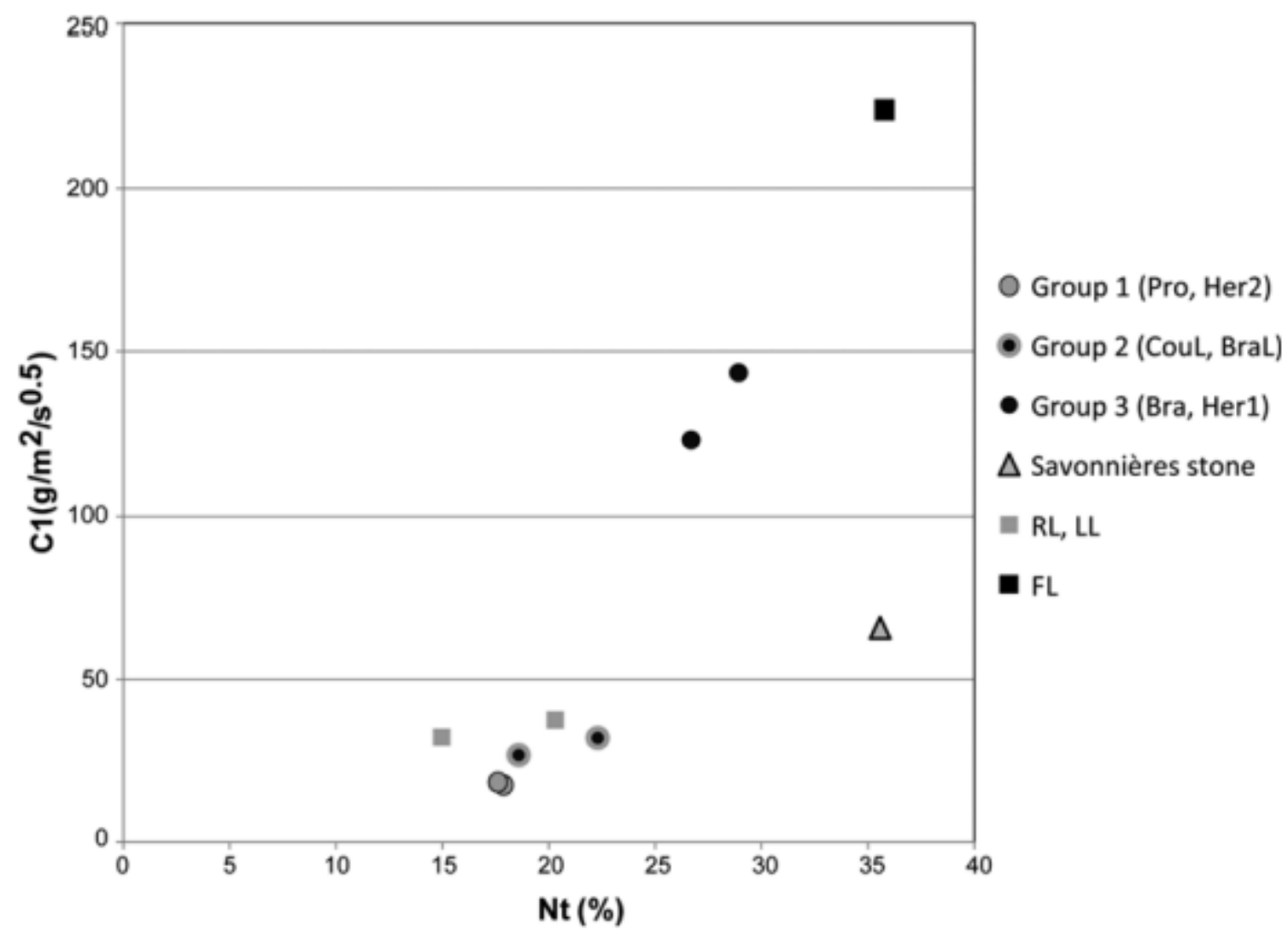

Fig. 9. Capillary absorption coefficient C1 v. total porosity Nt. LL, 'Saint-Maximin Liais'; RL, 'Saint-Maximin roche franche'; FL, 'Saint-Maximin roche fine'.

The lower porosities (c. 18\%) of groups 1 and 2 were distinguished by the results of the mercury porosimetry, capillary and drying kinetics tests. The miliolid limestones (Group 2) had an unimodal pore-size distribution, with a mean pore access radius $(\mathrm{Rm})$ of about $0.1 \mathrm{~mm}$; this indicated a high capillary water uptake (c. $80 \%$ ) and a high critical saturation (from 55 to $70 \%$ ). That meant that a large proportion of water dried from the interior. The Ditrupa limestones Pro and Her2 (Group 1) had intermediate pore distributions and drying behaviour (Sc of c. 40\%) compared to the other Lutetian limestones. Only their capillary coefficients were lower than those of Groups 2 and 3.

The more porous limestones, Her1 and Bra (Group 3), had larger pores, with about $70 \%$ of them being between 0.2 and $16 \mathrm{~mm}$. Compared to the other limestones, water uptake coefficients were 10 times 
Turmel A., FRONTEAU G., C. Thomachot- Schneider, L. Chalumeau, V. Barbin. 2014. Stone uses in Reims Cathedral: provenance, physical properties and restoration phases. Stone in Historic Buildings: Characterization and Performance. Dir. Cassar J. SP391. Geological Society, London, p. 17-30. doi.org/10.1144/SP391.7Re

higher, but the capillary saturations (Ncap) were lower or similar (at c. 60\%). The amount of water remaining at the end of the first stage of drying (Sc) was quite low (c. 15\%), indicating that drying occurred mainly at the surface in these limestones.

Based on these results, the third group should be more resistant to salt weathering than the others. Because of their high critical saturations, Group 2 should be more sensitive to salt weathering than Group 1.

The connected porosity is the main factor determining the deterioration potential of the stone (Yu \& Oguchi 2010). Small pores (,5 mm) induce a higher crystallization pressure, and the salt precipitation will take place deeper beneath the stone surface (Benavente et al. 2004). Yu \& Oguchi (2010) developed a durability estimator (called the Salt Susceptibility Index, SSI) based on the pore characteristics of the materials. The SSI is calculated as follows:

$$
\mathrm{SSI}=(\mathrm{Ipc}+\mathrm{Ipm0.1})(\mathrm{Pm} 5 / \mathrm{Pc})
$$

where Ipc and Ipm0.1 are indices for specific intervals of connected porosity and for microporosity of less than $0.1 \mathrm{~mm}$, respectively; Pc corresponds to the total mercury porosity; and Pm0.1 and Pm5 represent volume percentages of pore smaller than 0.1 and $5 \mathrm{~mm}$, respectively. The results are presented in Table 2. An SSI value of ,4 indicates salt-resistant stone, whereas values .4 indicate saltprone stone (Yu \& Oguchi 2010).

All of the stones are classified as salt prone, except for Bra, which is classified as salt resistant (Table 2). However, the value for Her1 is close to 4, while the SSI factor is highest for BraL (7.22) and CouL (7.32). Calculation of the SSI factors confirmed the previous results: the group containing Bra and Her1 seems to be the least sensitive to weathering, but BraL and CouL are the stones most likely to be affected by salt.

The modern restoration stones were compared The effective porosity was plotted as a function of the absorption coefficient, C1 (Fig. 9). For the Saint-Maximin stone, from the miliolid limestones type ('Lambourdes et Vergelé'), three varieties exist: 'roche fine' (FL), which is a pale yellowish brown biodetritic limestone made of calcite and quartz grains; and 'liais' (LL) and 'roche franche' (RL), which are two pale yellowish brown biodetritic limestone (Angeli et al. 2008). LL and RL are mostly composed of calcite with traces of iron oxides and macrofossils. The fossils appear less sharp in LL than in RL owing to more dissolution and diagenetic calcite recrystallization (Angeli et al. 2008). These samples had the same porosity as BraL and CouL, but have slightly higher capillary kinetics. Moreover, they are also microporous, but with a grainsupported structure. In contrast, the quasi-unimodal pore access size distribution of $\mathrm{FL}$ is mainly distributed around $20 \mathrm{~mm}$ and corresponds to intergranular macroporosity. Its pore-size distribution is comparable to those of Group 3. However, the effective porosity and capillary coefficient are much higher than for all of the other limestones studied. Finally, only two facies of the Saint-Maximin - 'liais' (LL) and 'roche franche' (RL) - have properties comparable to the stones from the Cathedral. The Saint Maximin LL and RL, used as replacement stone for Groups 1 and 2 (Ditrupa limestones and miliolid limestones), should be suitable for use in the Cathedral. In this study, comparison of the original stones used and the replacement stones was based on the porosity and the capillary kinetics. The weathering effect and the durability, measured by freeze-thaw cycle and salt tests on climatic chamber, would complete the results obtained.

The other non-local restoration stone, the Savonnières stone, is an oolitic limestone that has a heterogeneous pore-size distribution, with macropores of around $200 \mathrm{~mm}$ corresponding to the dissolved nuclei of the oolithes and to micropores of around $0.1 \mathrm{~mm}$ (Roels et al. 2003) in the micritic 
Turmel A., FRONTEAU G., C. Thomachot- Schneider, L. Chalumeau, V. Barbin. 2014. Stone uses in Reims Cathedral: provenance, physical properties and restoration phases. Stone in Historic Buildings: Characterization and Performance. Dir. Cassar J. SP391. Geological Society, London, p. 17-30. doi.org/10.1144/SP391.7Re

phase. The macroporous network is not connected. This stone has a high effective porosity and a low capillary coefficient (for more details, see the CTMNC database: http://www.ctmnc.fr/ pages/cat_6.php), and, thus, is quite different from any local building stone of the Reims region (Fig. 9). Nevertheless, the mapping showed that it had been used for parts exposed to rain, such as caps and pinnacles. In such places, hidden from view, this stone would be more resistant than the local limestones.

Petrophysical measurements reveal the variabilities between quarries, as well as between the Lutetian formation of the local stones and the replacement stones. Further investigations of stones from more quarries may identify other suitable stone to match the requirements of the different parts of the monument.

\section{Conclusion}

Restoration is planned for Reims Cathedral, but the supply of stone used in much of its construction, the local Courville stone, is limited and the last quarry in the area closed in 2005. This stone was the main replacement stone during the twentieth century. Consequently, two approaches were investigated: first, the use of non-local limestones from the Paris Basin; and, second, the reopening of a quarry for restoration purposes.

As a result of the stone mapping in several parts of Reims Cathedral, it has become clear that various types of Lutetian limestones were used, thus contradicting the belief that the Courville stone represents all of the original building material. Therefore, this stone mapping needs to be completed.

Four Ditrupa limestones and two miliolid limestones from local quarries were analysed. The set of sampled limestones could be subdivided in three main groups according to their petrophysical properties and their salt susceptibility. These properties were not all exact matches for the restoration stones (the Saint-Maximin and Savonnie'res stones). The characterization of other local facies in several quarries is necessary in order to find the best replacement stones for restoration.

We gratefully acknowledge Mr Truillet, chief curator of the Cultural Heritage in the Champagne-Ardenne region, who permitted access to the restoration works on the Notre-Dame Cathedral of Reims restoration, and B. Decrock, who provided information on the restoration history of the Cathedral.

\section{References}

AFNOR 1999. AFNOR B10-613, Natural Stone Tests, Determination of Water Absorption Coefficient by Capillarity. Standard NF EN 1925. Association Franc, aise de Normalisation (AFNOR), Paris.

AFNOR 2007. AFNOR B10-615, Natural Stone Tests, Determination of Kreal Density and Apparent Density, and of Total and Open Porosity. Standard NF EN 1936. Association Franc,aise de Normalisation (AFNOR), Paris.

Angeli, M., Benavente, D., Bigas, J.-P., Menéndez, B., Hébert, R. \& David, C. 2008. Modification of the porous network by salt crystallization in experimentally weathered sedimentary stones. Materials and Structures, 41, 1091-1108, http://dx.doi.org/10. 1617/s11527-007-9308-z 
Turmel A., FRONTEAU G., C. Thomachot- Schneider, L. Chalumeau, V. Barbin. 2014. Stone uses in Reims Cathedral: provenance, physical properties and restoration phases. Stone in Historic Buildings: Characterization and Performance. Dir. Cassar J. SP391. Geological Society, London, p. 17-30. doi.org/10.1144/SP391.7Re

Beck, K. 2006. Etude des propriétés hydriques et des mécanismes d'altération de pierres calcaires à forte porosité. PhD thesis, Orleans University.

Benavente, D., Garci’a del Cura, M. A., Garcia-Guinea, J., Sanchez-Moral, S. \& Ordonez, S. 2004. Role of pore structure in salt crystallization in unsaturated porous stone. Journal of Crystal Growth, 260, 532-544, http://dx.doi.org/10.1016/j.enggeo. 2004.03.005

Blanc, A., Demailly, S. \& Orial, G. 1990. Reims (Marne, 51). Façade occidentale, portails central et latéral droit : analyses chimiques et étude de la polychromie. Essais de traitement de la pierre de Courville. Laboratoire de Recherche des Monuments Historiques (LRMH), Paris.

Blondeau, A. 1970. Le calcaire grossier du Bassin de Paris. Bulletin du BRGM, II, 4, 7-17.

Bousquié, P. 1979. Texture et porosite' des roches calcaires. PhD thesis, Pierre et Marie Curie University Paris VI.

Dunham, R. J. 1962. Classification of carbonate rocks according to depositional texture. In: Ham, W. E. (ed.) Classification of Carbonate Rocks. American Association of Petroleum Geologists, Memoirs, 1, 108-121.

Folk, R. L. 1959. Practical petrographical classification of limestones. American Association of Petroleum Geologists Bulletin, 43, 1-38.

Fröhlich, F. \& Schubnel, H. J. (eds) 2000. Le Lute'tien, la Pierre de Paris. Muse'um National d'Histoire Naturelle, Paris.

Fronteau, G., Moreau, C., Thomachot-Schneider, C. \& Barbin, V. 2010. Variability of some Lutetian building stones from the Paris Basin, from characterization to conservation. Engineering Geology, 115, 158-166, http://dx.doi.org/10.1016/j.enggeo.2009. 08.001

Gély, J. P. 1996. Le Lutétien du Bassin de Paris: de l'analyse séquentielle haute résolution à la reconstitution paléogéographique. Bulletin d'information des Géologues du Bassin de Paris, 34, 237.

Goudie, A. S. 1999. A comparison of the relative resistance of limestones to frost and salt weathering. Permafrost and Periglacial Processes, 10, 309-316.

Huyghe, D., Merle, D., Lartaud, F., Cheype, E. \& Emmanuel, L. 2012. Middle Lutetian climate in the Paris Basin: implications for a marine hotspot of paleobiodiversity. Facies, 58, 587-604, http://dx.doi.org/ 10.1007/s10347-012-0307-3

Hyslop, E. K. \& Albornoz-Parra, L. 2009. Developing a future repairs strategy for a sandstone city8: a petrographic investigation of building stone in Glasgow, Scotland. Materials Characterization 60, 636-643, http://dx.doi.org/10.1016/j.matchar.2008. 11.004

Kozlowski, R., Magiera, J., Weber, J. \& Haber, J. 1990. Decay and conversation of Pin'czo'w porous limestone. Part 1. Lithology and weathering. Studies in Conservation, 35, 205-210.

Lefèvre, R.-A., Ionescu, A., Ausset, P., Chabas, A., Girardet, F. \& Vince, F. 2007. Modelling of the calcareous stone sulphation in polluted atmosphere exposure in the field. In: Pr`ikryl, R. \& Smith, B. J. (eds) Building Stone Decay: From Diagenesis to Conservation. Geological Society, London, Special Publications, 271, 131-137. 
Turmel A., FRONTEAU G., C. Thomachot- Schneider, L. Chalumeau, V. Barbin. 2014. Stone uses in Reims Cathedral: provenance, physical properties and restoration phases. Stone in Historic Buildings: Characterization and Performance. Dir. Cassar J. SP391. Geological Society, London, p. 17-30. doi.org/10.1144/SP391.7Re

Leroux, L. \& Boutin, F. 1999. Urban atmospheric pollution and natural ageing of stones protected by water repellents. In: Sturm, P. J. \& Pischinger, R. (eds) Transport and Air Pollution: 8th International Symposium Including COST 319 Final Conference, Graz, Austria, 31 May-2 June. Technical University Graz, Institute for internal combustion engines and thermodynamic, Section IX/15.

Moreau, C. et al. 2008. Water-repellent and biocide treatments: Assessment of the potential combinations. Journal of Cultural Heritage, 9, 394-400, http://dx.doi.org/ 10.1016/j.culher.2008.02.002

Remy, J. M. 1993. Influence de la structure du milieu poreux carbonate sur les transferts d'eau et les changements de phase eau-glace, application à la durabilité au gel de roches calcaires de Lorraine. PhD thesis, Institut National Polytechnique de Lorraine.

Roels, S. S., Carmeliet, J. \& Hens, H. 2003. Modelling unsaturated moisture transport in heterogeneous limestone (Part 1. A Mesoscopic Approach). Transport in Porous Media, 52, 333-350.

Siegesmund, S., Grimm, W.-D., Du“rrast, H. \& Ruedrich, J. 2010. Limestones in Germany used as building stones: an overview. In: Smith, B. J., GomezHeras, M., Viles, H. A. \& Cassar, J. (eds) Limestone in the Built Environment: Present-Day Challenges for the Preservation of the Past. Geological Society, London, Special Publications, 331, 37-59, http://dx. doi.org/10-1144/SP331.4

Thomachot-Schneider, C., Gommeaux, M., Fronteau, G., Oguchi, C. T., Eyssautier, S. \& Kartheuser, B. 2011. A comparison of the properties and salt weathering susceptibility of natural and reconstituted stones of the Orval Abbey (Belgium). Environmental Earth Science, 63, 1447-1461, http://dx.doi.org/10.1007/ s12665-010-0743-8

Török, A., Forgo', L. Z., Vogt,T., Lo"bens, S., Siegesmund, S. \& Weiss, T. 2007. The influence of lithology and pore-size distribution on the durability of acid volcanic tuffs, Hungary. In: Pr`ikryl, R. \& Smith, B. J. (eds) Building Stone Decay: From Diagenesis to Conservation. Geological Society, London, Special Publications, 271, 251-206.

Unterwurzacher, M., Obojes, U., Hofer, R. \& Mirwald, P. W. 2010. Petrophysical properties of selected Quaternary building stones in Western Austria. In: Prikryl, R. \& Török, A. (eds) Natural StoneResources for Historical Monuments. Geological Society, London, Special Publications, 333, 143-152, http://dx.doi.org/10.1144/SP333.14

Vergès-Belmin, V. 1992. Cathédrale Notre-Dame. Nef, ange du contrefort sud: étude de la pierre et de ses altérations. Laboratoire de Recherche des Monuments Historiques (LRMH), Paris.

Viré, M. 1997. Le nom des bancs exploités dans le calcaire grossier à Paris: étymologie et géologie. Journées Claude Lorenz, November, 183-186.

Yu, S. \& Oguchi, C. T. 2010. Role of pore distribution in salt uptake, damage, and predicting salt susceptibility of eight Japanese building stones. Engineering Geology, 115, 226-236, http://dx.doi.org/10.1016/ j.enggeo.2009.05.007 